\title{
Anionic Nanochanneled Silver-Deficient Oxalatochromate(III) Complex with Hydroxonium as Counter Ion: Synthesis, Characterization and Crystal Structure
}

\author{
Clémence T. Eboga ${ }^{1}$, Gouet Bebga ${ }^{2}$, Yves A. Mbiangué ${ }^{3}$, Emmanuel N. Nfor ${ }^{4}$, \\ Patrick L. Djonwouo ${ }^{1}$, Michel M. Bélombé1, Justin Nenwa ${ }^{{ }^{*}}$ \\ ${ }^{1}$ Inorganic Chemistry Department, University of Yaounde, Yaounde, Cameroon \\ ${ }^{2}$ Chemistry Department, Higher Teacher Training College, University of Yaounde 1, Yaounde, Cameroon \\ ${ }^{3}$ Chemistry Department, Higher Teacher Training College, University of Maroua, Maroua, Cameroon \\ ${ }^{4}$ Department of Chemistry, University of Buea, Buea, Cameroon \\ Email: *jnenwa@yahoo.fr
}

How to cite this paper: Eboga, C.T., Bebga, G., Mbiangué, Y.A., Nfor, E.N., Djonwouo, P.L., Bélombé, M.M. and Nenwa, J. (2017) Anionic Nanochanneled SilverDeficient Oxalatochromate(III) Complex with Hydroxonium as Counter Ion: Synthesis, Characterization and Crystal Structure. Open Journal of Inorganic Chemistry, 7, 75-87.

https://doi.org/10.4236/ojic.2017.73005

Received: May 18, 2017

Accepted: July 15, 2017

Published: July 18, 2017

Copyright (c) 2017 by authors and Scientific Research Publishing Inc. This work is licensed under the Creative Commons Attribution International License (CC BY 4.0).

http://creativecommons.org/licenses/by/4.0/ (c) (i) Open Access

\begin{abstract}
Reaction of $\mathrm{Ba}_{0.50}\left[\mathrm{Ag}_{2} \mathrm{Cr}\left(\mathrm{C}_{2} \mathrm{O}_{4}\right)_{3}\right] \cdot 5 \mathrm{H}_{2} \mathrm{O}$ with $\mathrm{Ag}_{2} \mathrm{SO}_{4}$ in an aqueous solution of sulfuric acid $(\mathrm{pH} \approx 3)$ yielded the silver(I)/chromium(III) oxalate salt $\mathrm{H}_{0.50}\left[\mathrm{Ag}_{2.50} \mathrm{Cr}\left(\mathrm{C}_{2} \mathrm{O}_{4}\right)_{3}\right] \cdot 5 \mathrm{H}_{2} \mathrm{O}$ (1). Compound 1 can be best described as an anionic silver-deficient oxalatochromate(III) complex $\left[\mathrm{Ag}_{2.50} \mathrm{Cr}\left(\mathrm{C}_{2} \mathrm{O}_{4}\right)_{3}\right]^{0.5-}$ with nanochannels containing hydrogen-bonded water molecules and protons. Thermal analyses show significant weight losses corresponding to the elimination of water molecules of crystallization followed by the decomposition of the network.
\end{abstract}

\section{Keywords}

Silver-Deficient Oxalatochromate(III), Water-Filled Nanochannels, Protons, Thermal Analysis, Crystal Structure

\section{Introduction}

Recent advances in the field of chemistry have triggered the emergence of new open framework materials with a wide range of exotic properties which are expected to promote modern technologies. These so-called "multifunctional materials" may, indeed, be exploited in many domains such as catalysis [1] [2] [3], magnetism [4], non-linear optics [5], gas storage [6] [7] and separation processes [8], to mention just a few examples. Multidentate organic ligands are usually used in the construction of open framework materials, amongst which 
oxalate is one of the simplest connectors potentially able to bridge metal ions in the bidentate chelating manner. The use of molecular building units such as tris(oxalato)metalate(III) anions, $\left[\mathrm{M}^{\mathrm{III}}\left(\mathrm{C}_{2} \mathrm{O}_{4}\right)_{3}\right]^{3-}$, has opened up tremendous possibilities for research in this area, giving rise to new compounds exhibiting a variety of nanostructured features [9] [10].

In the course of the past few years, the tris-chelated chromium complex anion, $\left[\mathrm{Cr}\left(\mathrm{C}_{2} \mathrm{O}_{4}\right)_{3}\right]^{3-}$, has been used to develop a series of silver-deficient nonmolecular coordination polymers with a variable Ag-Cr-oxalate channel lattice, formulated as $\left[\left(\mathrm{M}_{\mathrm{x}} \mathrm{Ag} \mathrm{g}_{0.50-\mathrm{x}}\right)\left(\mathrm{H}_{2} \mathrm{O}\right)_{3}\right] @\left[\mathrm{Ag}_{2.50} \mathrm{Cr}\left(\mathrm{C}_{2} \mathrm{O}_{4}\right)_{3}\right](0 \leq \mathrm{x} \leq 0.50 ; \mathrm{M}=\mathrm{K}, \mathrm{Cs}, \mathrm{Ag})$ [11]. Obviously, this formulation suggests a broad range of flexible synthetic manoeuvres for the preparation of this category of materials. In fact, by changing in a subtle manner, the quantity of reactants in presence, new values of deficiency in $\mathrm{Ag}^{+}$ions can be generated, and consequently, new chemical compositions of the negatively charged lattice grid $\left[\mathrm{Ag}_{3-\mathrm{x}} \mathrm{Cr}\left(\mathrm{C}_{2} \mathrm{O}_{4}\right)_{3}\right]^{\mathrm{x}-}(0<\mathrm{x} \leq 1)$ can be obtained.

Recently, our research group reported a closely related channel lattice network with chemical composition $\left[\mathrm{Ag}_{2.90} \mathrm{Cr}\left(\mathrm{C}_{2} \mathrm{O}_{4}\right)_{3}\right]^{0.10-}$, where the silver charge deficit $(0.10)$ per formula unit is solely compensated by an equivalent charge from 0.10 proton embedded amongst hydrogen-bonded water molecules within the channels [12]. Such systems with protons residing within "stagnating water streams" could be suitable to monitor proton transport processes in the solid state [12] [13] [14].

In the present work, we aimed to widen the scope of this family of nanochanneled coordination polymers, a special emphasis being set on increasing the amount of protons within the channels defined by the negative host lattice grid substantially. Herein, we report a novel open framework silver-deficient oxalatochromate(III) compound, $\mathrm{Ag}_{2.50} \mathrm{H}_{0.50}\left[\mathrm{Cr}\left(\mathrm{C}_{2} \mathrm{O}_{4}\right)_{3}\right] \cdot 5 \mathrm{H}_{2} \mathrm{O}$ (1). Its host lattice grid has the chemical composition $\left[\mathrm{Ag}_{2.50} \mathrm{Cr}\left(\mathrm{C}_{2} \mathrm{O}_{4}\right)_{3}\right]^{0.50-}$, accusing a deficiency of 0.50 in $\mathrm{Ag}^{+}$ion per formula unit which is compensated by an equivalent charge from $0.50 \mathrm{H}^{+}$, the highest amount of protons known so far for this family of materials.

\section{Experimental}

\subsection{Materials and Physical Measurements}

Elemental analysis for carbon and hydrogen was performed on a Vario EL (Heraeus) CHNS analyzer. The infrared spectrum $\left(4000-400 \mathrm{~cm}^{-1}\right)$ of the solid sample was recorded on a Perkin-Elmer 2000 FT-IR spectrometer as KBr disks. UV/Vis spectrum of the solution was measured on an AQUALYTIC spectrophotometer in the range $300-800 \mathrm{~nm}$. Thermal analyses (TGA and DSC) were performed with a Mettler Toledo TGA/SDTA 851 thermal analyzer. The powdered sample (ca. $15 \mathrm{mg}$ ) was heated in air atmosphere from $25^{\circ} \mathrm{C}$ to $500^{\circ} \mathrm{C}$ with a rate of $10^{\circ} \mathrm{C} \mathrm{min}^{-1}$.

\subsection{Synthesis}

$\mathrm{Ag}_{2} \mathrm{SO}_{4}$ and $\mathrm{H}_{2} \mathrm{SO}_{4}$ (Riedel de Haën) were used as purchased. The precursor salt $\mathrm{Ba}_{0.50}\left[\mathrm{Ag}_{2} \mathrm{Cr}\left(\mathrm{C}_{2} \mathrm{O}_{4}\right)_{3}\right] \cdot 5 \mathrm{H}_{2} \mathrm{O}$ was prepared as described in the literature [15]. 
Powder of $\mathrm{Ag}_{2} \mathrm{SO}_{4}(0.16 \mathrm{~g}, 0.5 \mathrm{mmol})$ was added in successive small portions to a stirred aqueous solution $(50 \mathrm{~mL})$ of $\mathrm{Ba}_{0.50}\left[\mathrm{Ag}_{2} \mathrm{Cr}\left(\mathrm{C}_{2} \mathrm{O}_{4}\right)_{3}\right] \cdot 5 \mathrm{H}_{2} \mathrm{O}(1.38 \mathrm{~g}, 2$ mmol) acidified with 2 drops of concentrated $\mathrm{H}_{2} \mathrm{SO}_{4}$. After 2 hours of stirring at $70^{\circ} \mathrm{C}$, the mixture was cooled to room temperature and a white precipitate of $\mathrm{BaSO}_{4}$ was filtered off. The resulting indigo-blue solution was allowed to evaporate in a hood at room temperature. Elongated violet needle-shaped crystals suitable for X-ray diffraction were formed within ten days. Anal. Calcd. for $\mathrm{C}_{6} \mathrm{H}_{10.50} \mathrm{Ag}_{2.50} \mathrm{CrO}_{17}\left(676.30 \mathrm{~g} \mathrm{~mol}^{-1}\right)$ : C, 10.66; H, 1.56\%. Found: C, 10.51; H, 1.48\%. IR (KBr, cm $\left.{ }^{-1}\right): v=3587(\mathrm{w}), 3246(\mathrm{w}), 1623$ (s), $1378(\mathrm{~s}), 1258(\mathrm{w}), 899$ (w), 801 (s), 543 (s), 474 (s). UV-Vis $\left(\mathrm{H}_{2} \mathrm{O}\right.$ solution, $\left.\mathrm{nm}\right): 430 ; 570$.

\subsection{X-Ray Crystallography}

A violet crystal with dimensions $0.38 \times 0.32 \times 0.20 \mathrm{~mm}^{3}$ was taken directly out of the mother liquor, immersed in perfluorinated polyether, and fixed on top of a glass capillary. Graphite monochromated Mo K $\alpha$ radiation $(\lambda=0.71073 \AA$ ) was used throughout. Intensity data were collected on a Siemens SMART CCD-detector. The temperature was set to $293 \mathrm{~K}$. Data collection was performed by a hemisphere run taking 20 frames at intervals of $0.3^{\circ}$ about $\omega$. The data were corrected for Lorentz and polarization effects. A multi-scan absorption correction using the program SADABS [16] was performed for the compound. The structure was solved and refined by the direct methods and Fourier techniques. All non-hydrogen atoms were refined anisotropically. All hydrogen atoms were placed at calculated positions and refined as riding atoms with isotropic displacement parameters. For structure solving and refinement the software package SHELXTL [17] [18] was used. The ORTEP-3 program [19] was used within the WinGX software package [20] to deal with the processed crystallographic data and artwork representations. Crystallographic data and refinement parameters are listed in Table 1.

\section{Results and Discussion}

\subsection{Formation of $\mathrm{Ag}_{2.50} \mathrm{H}_{0.50}\left[\mathrm{Cr}\left(\mathrm{C}_{2} \mathrm{O}_{4}\right)_{3}\right] \cdot 5 \mathrm{H}_{2} \mathrm{O}$ (1)}

Reaction of $\mathrm{Ag}_{2} \mathrm{SO}_{4}$ with $\mathrm{Ba}_{0.50}\left[\mathrm{Ag}_{2} \mathrm{Cr}\left(\mathrm{C}_{2} \mathrm{O}_{4}\right)_{3}\right] \cdot 5 \mathrm{H}_{2} \mathrm{O}$ in an aqueous solution of $\mathrm{H}_{2} \mathrm{SO}_{4}$ acid $\left(\mathrm{pH} \approx 3\right.$ ) afforded the compound $\mathrm{Ag}_{2.50} \mathrm{H}_{0.50}\left[\mathrm{Cr}\left(\mathrm{C}_{2} \mathrm{O}_{4}\right)_{3}\right] \cdot 5 \mathrm{H}_{2} \mathrm{O}(1)$ as violet needles. This acidic medium may be responsible for the easy formation of the title compound. Compound $\mathbf{1}$ is an air-stable material which does not melt up to $250^{\circ} \mathrm{C}$.

\subsection{Characterization of 1}

The FTIR spectrum of 1 (Figure 1) shows two broad bands at $3587 \mathrm{~cm}^{-1}$ and $3246 \mathrm{~cm}^{-1}$ which are assigned to water molecules of hydration within the channels. The bands centered at $1623 \mathrm{~cm}^{-1}, 1378 \mathrm{~cm}^{-1}$ and $1258 \mathrm{~cm}^{-1}$ are attributed to $v(\mathrm{C}=\mathrm{O}), v(\mathrm{C}-\mathrm{O})$ and $\mathrm{C}-\mathrm{C}$ stretches respectively, as expected for oxalate ligands [21] [22]. The sharp bands observed at $543 \mathrm{~cm}^{-1}$ and $474 \mathrm{~cm}^{-1}$ can be assigned to the $\mathrm{Cr}-\mathrm{O}$ and $\mathrm{Ag}-\mathrm{O}$ vibrations respectively [12] [15]. 
The UV-V is spectrum of 1 (Figure 2) reveals two absorption bands at 430 $\mathrm{nm}\left(23,256 \mathrm{~cm}^{-1}\right)$ and $570 \mathrm{~nm}\left(17,544 \mathrm{~cm}^{-1}\right)$ which correspond to ${ }^{4} \mathrm{~A}_{2 \mathrm{~g}}(\mathrm{~F}) \rightarrow$ ${ }^{4} \mathrm{~T}_{1 \mathrm{~g}}(\mathrm{~F})$ and ${ }^{4} \mathrm{~A}_{2 \mathrm{~g}}(\mathrm{~F}) \rightarrow{ }^{4} \mathrm{~T}_{2 \mathrm{~g}}(\mathrm{~F})$ (d-d) transitions within the octahedral complex ions $\left[\mathrm{Cr}\left(\mathrm{C}_{2} \mathrm{O}_{4}\right)_{3}\right]^{3-}$ contained in 1 respectively [12] [13] [14] [15]. Obviously, the

Table 1. Crystal data and structure refinement for 1.

\begin{tabular}{|c|c|}
\hline Empirical formula & $\mathrm{C}_{6} \mathrm{H}_{10.5} \mathrm{Ag}_{2.5} \mathrm{CrO}_{17}$ \\
\hline Formula weight & 676.30 \\
\hline $\mathrm{T}(\mathrm{K})$ & $293(2)$ \\
\hline Wavelength $(\AA)$ & 0.71073 \\
\hline Crystal system & monoclinic \\
\hline Space group & $C 2 / \mathrm{c}$ \\
\hline \multicolumn{2}{|l|}{ Unit cell parameters } \\
\hline$a(\AA)$ & $18.230(3)$ \\
\hline$b(\AA)$ & $14.652(3)$ \\
\hline$c(\AA)$ & $12.276(3)$ \\
\hline$\alpha\left(^{\circ}\right)$ & 90 \\
\hline$\beta\left(^{\circ}\right)$ & $113.700(2)$ \\
\hline$\gamma\left({ }^{\circ}\right)$ & 90 \\
\hline$V\left(\AA^{3}\right)$ & $3002.4(11)$ \\
\hline$Z$ & 8 \\
\hline$D_{\text {calc }}\left(\mathrm{g} / \mathrm{cm}^{3}\right)$ & 2.981 \\
\hline$\mu\left(\mathrm{mm}^{-1}\right)$ & 4.03 \\
\hline$F(000)$ & 2572 \\
\hline Crystal size $(\mathrm{mm})$ & $0.38 \times 0.32 \times 0.20$ \\
\hline$\theta$ range for data collection $\left(^{\circ}\right)$ & $2.2-25.0$ \\
\hline Index ranges & $\begin{array}{c}-19 \leq \mathrm{h} \leq 21 \\
-17 \leq \mathrm{k} \leq 16 \\
-14 \leq 1 \leq 14\end{array}$ \\
\hline Total reflections & 7233 \\
\hline Unique reflections $\left(\mathrm{R}_{\text {int }}\right)$ & $2630(0.0236)$ \\
\hline Absorption correction & Multi-scan \\
\hline Refinement method & Full-matrix least squares on $F^{2}$ \\
\hline Data/restraints/parameters & $2630 / 0 / 240$ \\
\hline Goodness-of-fit (GOF) on $F 2$ & 1.07 \\
\hline$R$ factor $[I>2 \sigma(I)]$ & $R_{1}=0.0784, w R_{2}=0.2312$ \\
\hline$R$ factor (all data) & $R_{1}=0.0814, w R_{2}=0.2282$ \\
\hline Largest diff. peak and hole $\left(\mathrm{e} \AA^{-3}\right)$ & 2.42 and -3.60 \\
\hline
\end{tabular}




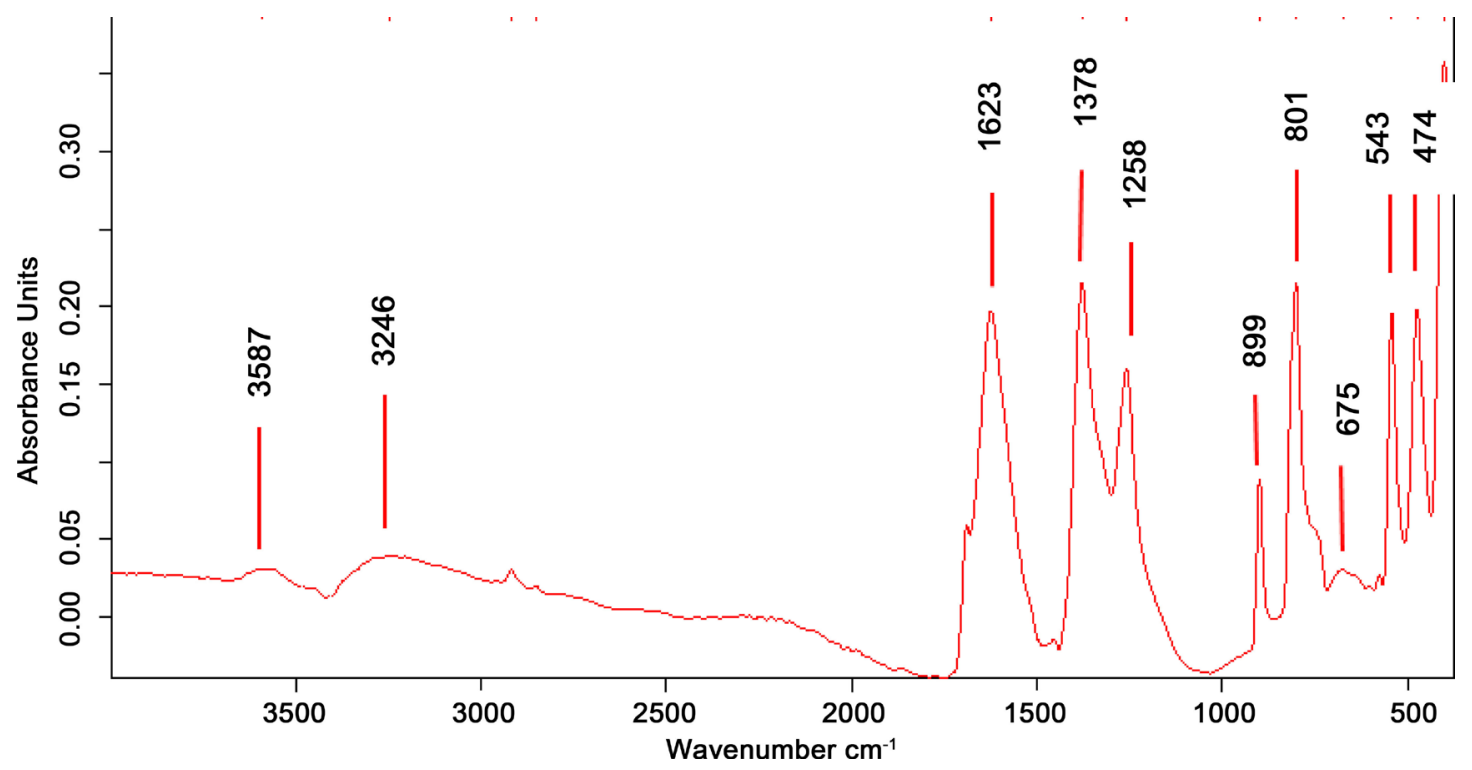

Figure 1. Infrared absorption spectrum of compound 1.

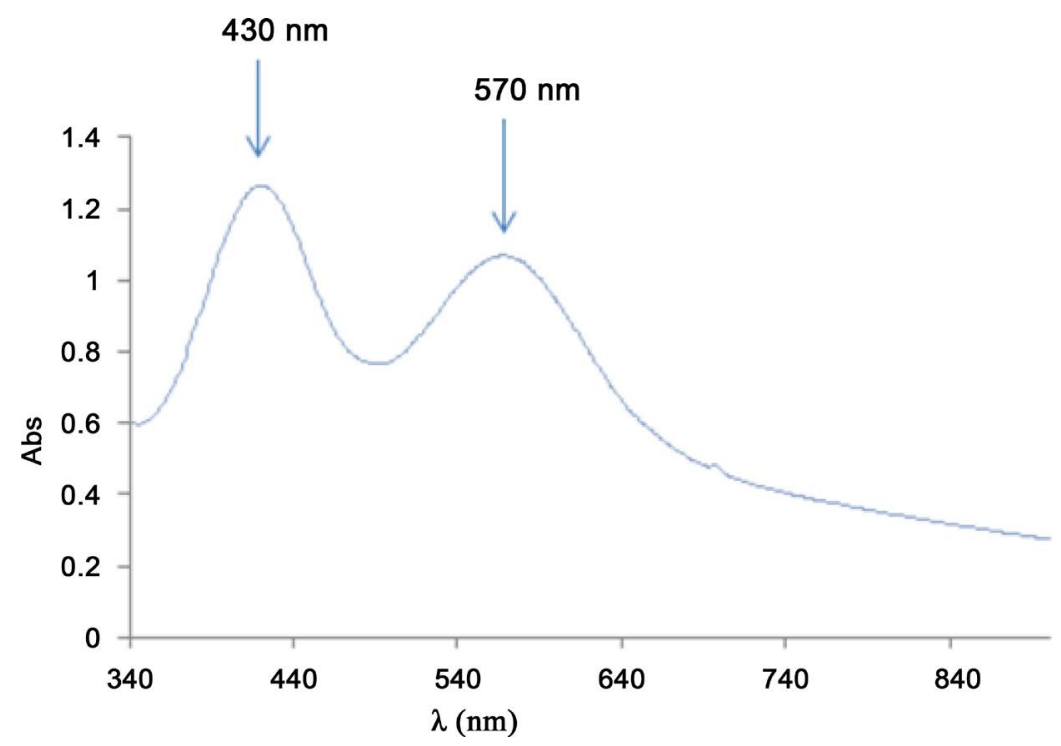

Figure 2. Electronic absorption spectrum of compound 1.

present electronic absorption spectrum is virtually super imposable with that reported since the spectral informations thus obtained solely relate to the $\left[\mathrm{Cr}\left(\mathrm{C}_{2} \mathrm{O}_{4}\right)_{3}\right]^{3-}$ species.

The TG curve of 1 depicted in Figure 3 evidences three distinct weight losses in the temperature range $50^{\circ} \mathrm{C}-360^{\circ} \mathrm{C}$, the first process being endothermic and the two others exothermic. In the temperature range $80^{\circ} \mathrm{C}-100^{\circ} \mathrm{C}$, compound 1 suffers a first weight loss of 5.86\% (calc. 5.32\%) corresponding the release of two out of five water molecules of hydration. A second weight loss of $23.08 \%$ (calc. 23.07\%) occurs between $263^{\circ} \mathrm{C}$ and $320^{\circ} \mathrm{C}$, corresponding to the decomposition of the framework with release of $5 / 2 \mathrm{CO}_{2}+3 \mathrm{H}_{2} \mathrm{O}$. From $320^{\circ} \mathrm{C}$ to $360^{\circ} \mathrm{C}$, a third weight loss of $4.40 \%$ (calc. $4.58 \%$ ) is consistent with the release of $1 / 2 \mathrm{CO}_{2}+1 / 2$ $\mathrm{H}_{2} \mathrm{O}$, the final residue being a mixture of $\mathrm{Ag}_{2} \mathrm{O}$ and $\mathrm{Cr}_{2} \mathrm{O}_{3}$. 


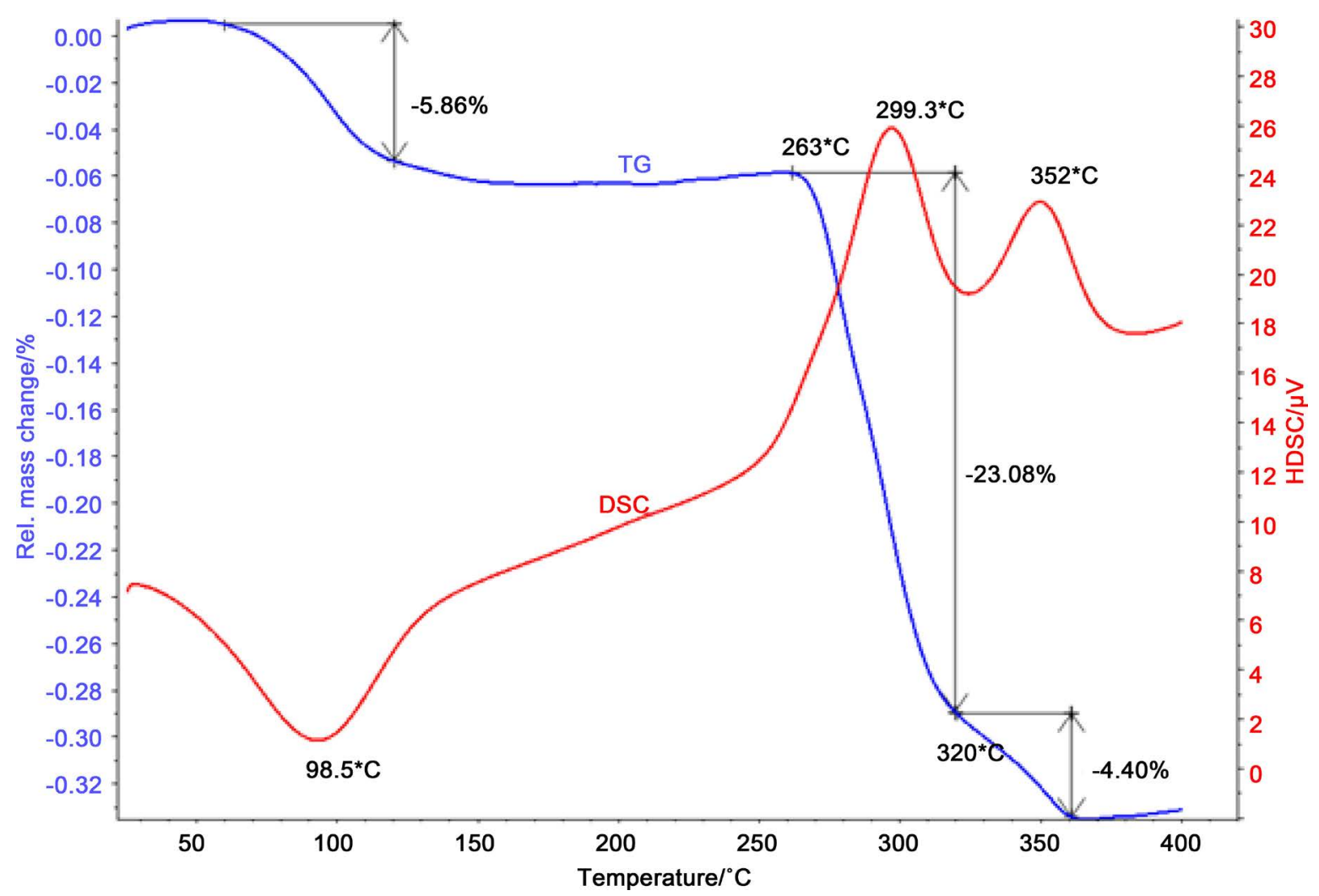

Figure 3. TG curve (blue) and DSC curve (red) of compound 1.

\subsection{Crystal Structure of 1}

The solid state structure of $1, \mathrm{Ag}_{2.50} \mathrm{H}_{0.50}\left[\mathrm{Cr}\left(\mathrm{C}_{2} \mathrm{O}_{4}\right)_{3}\right] \cdot 5 \mathrm{H}_{2} \mathrm{O}$, has been established by single-crystal X-ray diffraction. Compound 1 crystallizes, like many other members of open-framework silver-deficient oxalate chromate(III) salts [11] [13] [23] [24], in the monoclinic space group $C 2 / c$. The environment of the metallic centers in 1 is illustrated in Figure 4. Each $\mathrm{Cr}^{\mathrm{III}}$ site (Figure 4(a)) is hexacoordinated by the hydroxylic $\mathrm{O}$ atoms $(\mathrm{O} 2, \mathrm{O} 3, \mathrm{O} 6, \mathrm{O} 7, \mathrm{O} 9, \mathrm{O} 12)$ of three oxalate ligands to give the well-established pseudo-octahedral $\left[\mathrm{Cr}\left(\mathrm{C}_{2} \mathrm{O}_{4}\right)_{3}\right]^{3-}$ complex anion. The three oxalate ligands of the $\left[\mathrm{Cr}\left(\mathrm{C}_{2} \mathrm{O}_{4}\right)_{3}\right]^{3-}$ complex bridge to the three crystallographycally different Ag atoms Ag1, Ag2, and Ag3. The Ag1 site (Figure 4(b)) experiences distorted pentacoordination geometry, being linked in a monodentate manner to three oxalate $\mathrm{O}$ atoms $(\mathrm{O} 1, \mathrm{O} 4, \mathrm{O} 9)$ and chelated by the oxalate $\mathrm{O}$ atoms (O5, O8). By contrast, $\mathrm{Ag} 2$ and $\mathrm{Ag} 3$ sites (Figure 4(c), Figure 4(d)) are six-coordinate. The Ag2 ion sits on an inversion center of a strongly distorted $(2+2+2)$ octahedron involving two chelating oxalate $\mathrm{O}$ atoms (O10, $\mathrm{O} 11)$ and two monodentate oxalate $\mathrm{O}$ atoms (O6). The Ag3 ion is chelated by an oxalate through $\mathrm{O} 1$ and $\mathrm{O} 4$ atoms and bonded in a monodentate manner to the oxalate $\mathrm{O}$ atoms $\mathrm{O} 10, \mathrm{O} 12, \mathrm{O} 24$ and a nonbonding $\mathrm{Ag} \cdots \mathrm{Ag} 3^{\mathrm{iii}}$ separation of 3.173(3) $\AA$ completes the hexacoordination around this site. Relevant interatomic distances and angles are given in Table 2. The Ag-O bond lengths and $\mathrm{O}-\mathrm{Ag}-\mathrm{O}$ bond angles fit well within the ranges of previous results [11] [12] [13] [23] [24]. Figure 5 shows a lattice packing of the unit cell of 1 projected down 


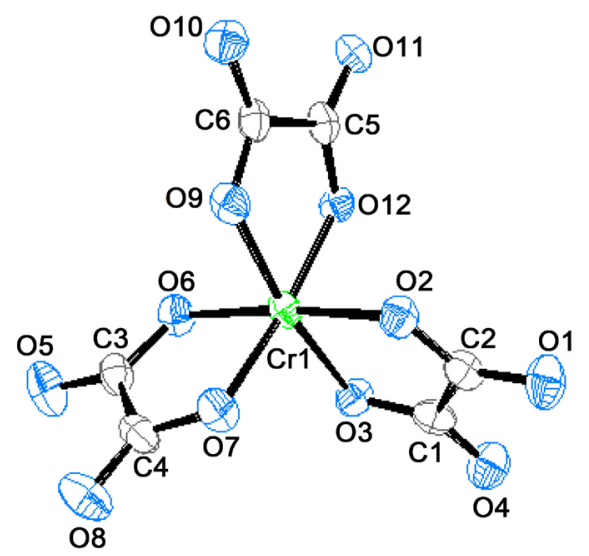

(a)

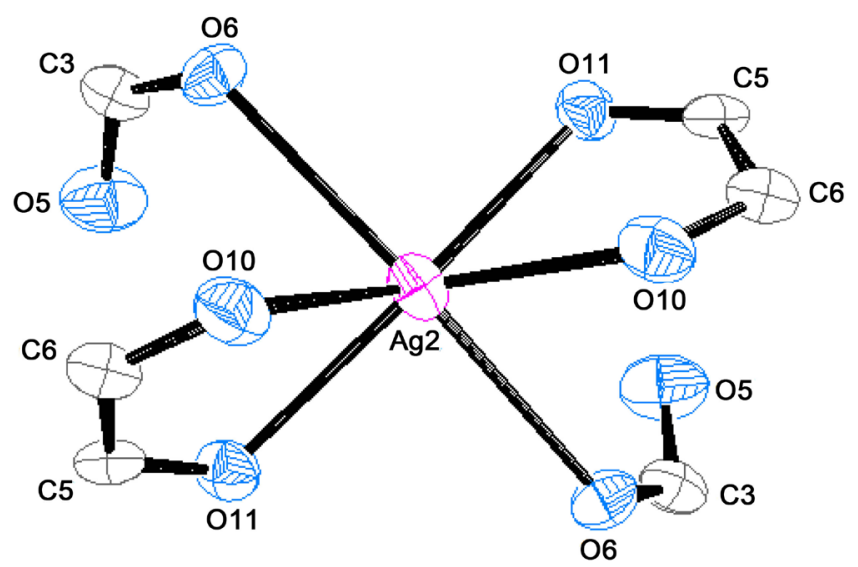

(c)

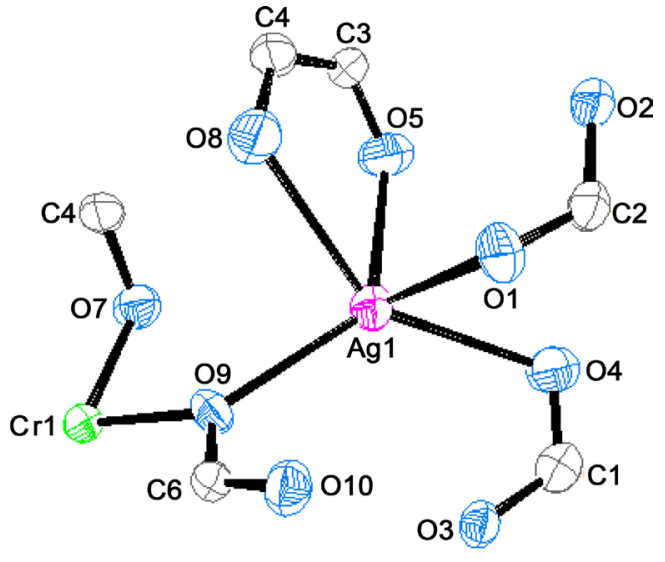

(b)

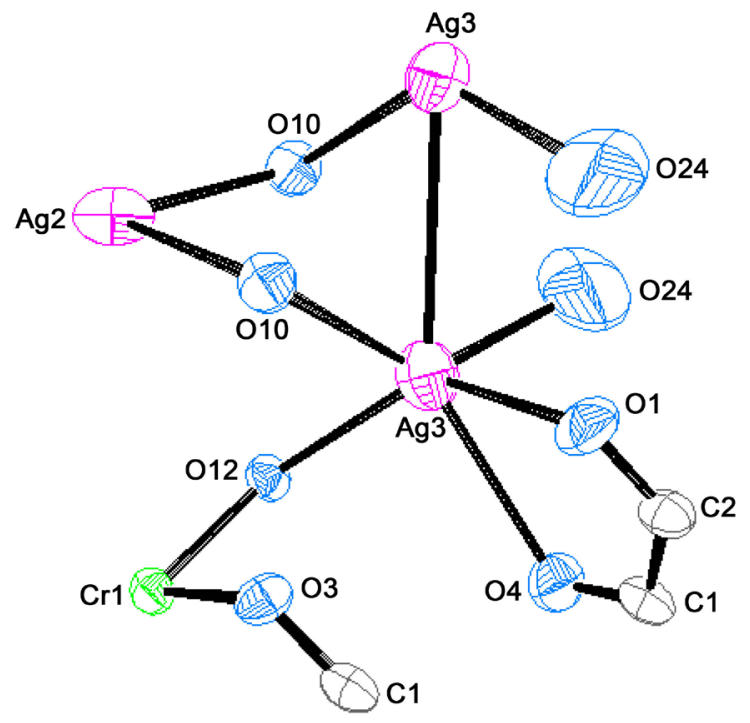

(d)

Figure 4. Environment of the metallic centers in 1: $\operatorname{Cr}(\mathrm{a}), \operatorname{Ag} 1$ (b), $\operatorname{Ag} 2$ (c) and Ag3 (d).

[001] highlighting four halves of tubular channels filled with water molecules. The structure of 1 can be best described as a silver-deficient oxalatochromate(III) salt where one of the three $\mathrm{Ag}^{+}$ions is partially replaced by $\mathrm{H}^{+}$, the anionic building blocks which delineate tubular channels being $\left[\mathrm{Ag}_{2.50} \mathrm{Cr}\left(\mathrm{C}_{2} \mathrm{O}_{4}\right)_{3}\right]^{0.50-}$. Thus, it is obvious that the fractional $\left(0.50 \mathrm{H}^{+}\right)$ proton balancing the charge of the anionic building block is attached to a water molecule within the channels. The compound is therefore better formulated as $\left[\mathrm{H}_{0.50} \mathrm{H}_{2} \mathrm{O}\right] @\left[\mathrm{Ag}_{2.50} \mathrm{Cr}\left(\mathrm{C}_{2} \mathrm{O}_{4}\right)_{3}\right] \cdot 4 \mathrm{H}_{2} \mathrm{O}$. The protonated and neutral water molecules included in the channels are hydrogen-bonded to each other and to surrounding oxalate $\mathrm{O}$ atoms. The five water molecules of crystallization found in the crystal structure of 1 build water clusters inside the channels through hydrogen bonds shown as broken lines in Figure 6.

A large cross-section of the three-dimensional structure packing of 1 projected down [001] is depicted in Figure 7, highlighting the fact that the pseu- 
Table 2. Selected bond lengths $(\AA)$ and angles $\left(^{\circ}\right)$ within the coordination spheres around the metal centers in $\mathbf{1}$.

\begin{tabular}{|c|c|c|c|}
\hline $\mathrm{Cr} 1-\mathrm{O} 2$ & $1.969(8)$ & $\mathrm{O} 7^{\mathrm{vi}}-\mathrm{Cr} 1-\mathrm{O} 2$ & $93.1(3)$ \\
\hline $\mathrm{Cr} 1-\mathrm{O} 3$ & $1.962(7)$ & $\mathrm{O} 6^{\mathrm{vi}}-\mathrm{Cr} 1-\mathrm{O} 3$ & $94.5(3)$ \\
\hline $\mathrm{Cr} 1-\mathrm{O}^{\mathrm{vi}}$ & $1.958(8)$ & $\mathrm{O} 6^{\mathrm{vi}}-\mathrm{Cr} 1-\mathrm{O} 9^{\mathrm{vii}}$ & $91.7(3)$ \\
\hline $\mathrm{Cr} 1-\mathrm{O}^{\mathrm{vi}}$ & $1.956(7)$ & $\mathrm{O}^{\mathrm{vi}}-\mathrm{Cr} 1-\mathrm{O}^{\mathrm{vii}}$ & $93.9(3)$ \\
\hline $\mathrm{Cr} 1-\mathrm{O}^{\mathrm{vii}}$ & $1.973(7)$ & $\mathrm{O} 2-\mathrm{Cr} 1-\mathrm{O} 9^{\mathrm{vii}}$ & $92.0(3)$ \\
\hline $\mathrm{Cr} 1-\mathrm{O} 12^{\mathrm{vii}}$ & $1.976(7)$ & $\mathrm{O} 6^{\mathrm{vi}}-\mathrm{Cr} 1-\mathrm{O} 12^{\mathrm{vii}}$ & $93.2(3)$ \\
\hline Ag1-O9 & $2.333(7)$ & O9-Ag1-O5 & $130.1(3)$ \\
\hline Ag1-O5 & $2.408(9)$ & O5-Ag1-O4 & $91.2(3)$ \\
\hline Ag1-O4 & $2.412(8)$ & O9-Ag1-O4 & $130.0(3)$ \\
\hline Ag1-O8 & $2.572(9)$ & O9-Ag1-O8 & $83.4(3)$ \\
\hline $\mathrm{Ag} 1-\mathrm{O} 1^{\mathrm{i}}$ & $2.686(9)$ & $\mathrm{O} 9-\mathrm{Ag} 1-\mathrm{O} 1^{\mathrm{i}}$ & $108.5(3)$ \\
\hline Ag2-O11 & $2.370(7)$ & O11-Ag2-O10 & $70.2(2)$ \\
\hline $\mathrm{Ag} 2-\mathrm{O} 11^{\mathrm{iv}}$ & $2.370(7)$ & $\mathrm{O} 11^{\mathrm{iv}}-\mathrm{Ag} 2-\mathrm{O} 10^{\mathrm{iv}}$ & $70.2(2)$ \\
\hline Ag2-O10 & $2.505(8)$ & $\mathrm{O} 11^{\mathrm{iv}}-\mathrm{Ag} 2-\mathrm{O} 10$ & $138.0(2)$ \\
\hline Ag2-O10 iv & $2.505(8)$ & $\mathrm{O} 11-\mathrm{Ag} 2-\mathrm{O} 10^{\mathrm{iv}}$ & $138.0(2)$ \\
\hline $\mathrm{Ag} 2-\mathrm{O}^{\mathrm{v}}$ & $2.618(7)$ & $\mathrm{O} 11-\mathrm{Ag} 2-\mathrm{O}^{\mathrm{v}}$ & $84.6(2)$ \\
\hline $\mathrm{Ag} 2-\mathrm{O}^{\mathrm{vi}}$ & $2.618(7)$ & $\mathrm{O} 11^{\mathrm{iv}}-\mathrm{Ag} 2-\mathrm{O} 6^{\mathrm{vi}}$ & $84.6(2)$ \\
\hline $\mathrm{Ag} 3-\mathrm{O} 12^{\mathrm{ii}}$ & $2.322(7)$ & $\mathrm{O} 12^{\mathrm{ii}}-\mathrm{Ag} 3-\mathrm{O} 1$ & $135.7(3)$ \\
\hline Ag3-O1 & $2.446(9)$ & $\mathrm{O} 1-\mathrm{Ag} 3-\mathrm{O} 24$ & $96.1(7)$ \\
\hline $\mathrm{Ag} 3-\mathrm{O} 24$ & $2.640(3)$ & $\mathrm{O} 12^{\mathrm{ii}}-\mathrm{Ag} 3-\mathrm{O} 24$ & $113.2(6)$ \\
\hline $\mathrm{Ag} 3-\mathrm{O} 10^{\mathrm{i}}$ & $2.651(8)$ & $\mathrm{O} 1-\mathrm{Ag} 3-\mathrm{O} 10^{\mathrm{i}}$ & $88.1(3)$ \\
\hline $\mathrm{Ag} 3-\mathrm{O} 4$ & $2.664(9)$ & $\mathrm{O} 12^{\mathrm{ii}}-\mathrm{Ag} 3-\mathrm{O} 4$ & $85.7(2)$ \\
\hline $\mathrm{Ag} 3-\mathrm{Ag} 3^{\mathrm{iii}}$ & $3.173(3)$ & $\mathrm{O} 12^{\mathrm{ii}}-\mathrm{Ag} 3-\mathrm{Ag} 3^{\mathrm{iii}}$ & $125.60(18)$ \\
\hline
\end{tabular}

Symmetry transformations used to generate equivalent atoms for (1): (i) $-x+1 / 2,-y+1 / 2,-z+1$; (ii) $-x+$ $1 / 2, y+1 / 2,-z+1 / 2$; (iii) $-x+1, y,-z+3 / 2$; (iv) $-x, y,-z+1 / 2$; (v) $x-1 / 2, y-1 / 2, z$; (vi) $-x+1 / 2, y-1 / 2$, $-z+1 / 2 ;$ (vii) $x,-y, z+1 / 2$.

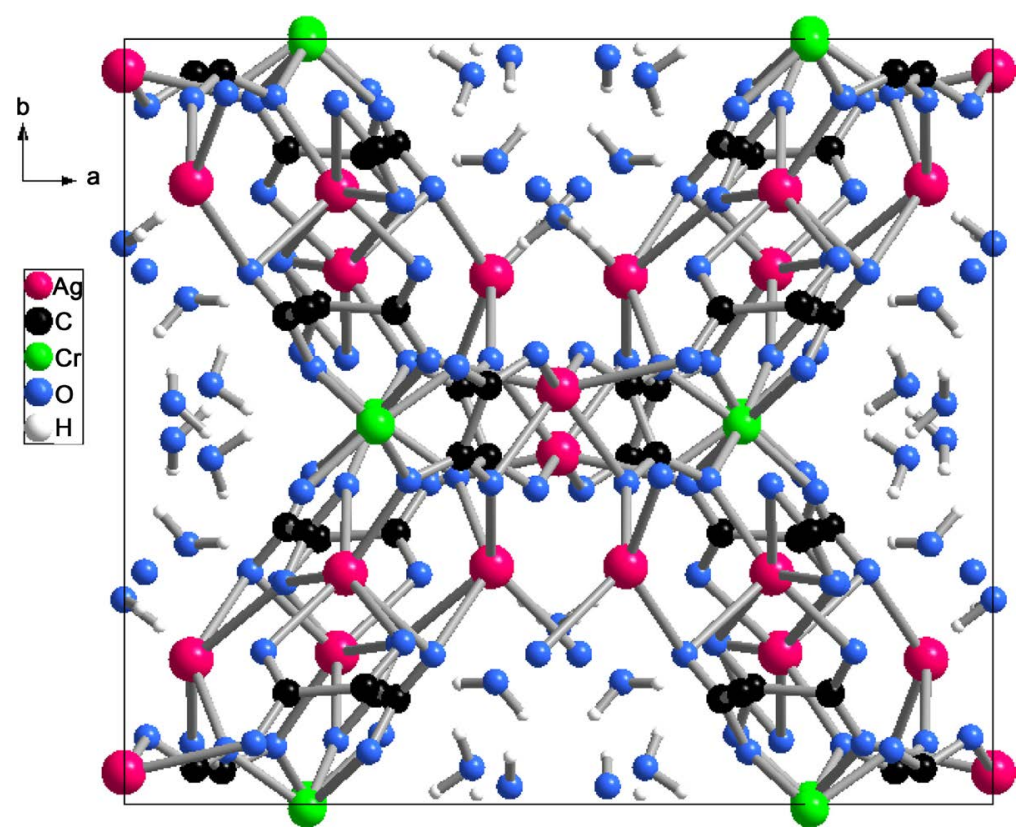

Figure 5. Lattice packing of the unit cell of 1 projected down [001] highlighting four halves of tubular channels filled with water molecules of crystallization. 

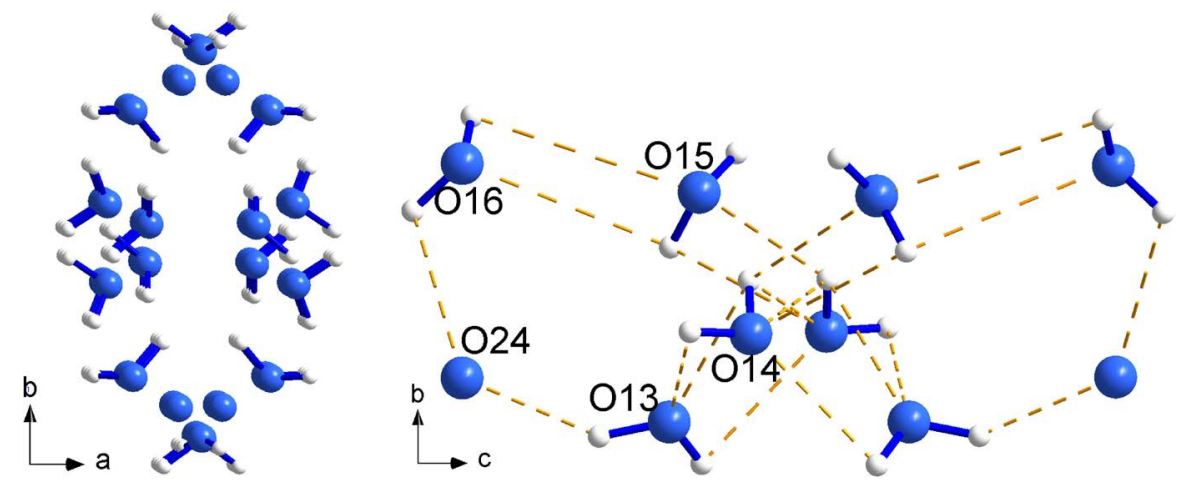

Figure 6. Five water molecules of crystallization found in the crystal structure of 1 forming water clusters inside the channels through hydrogen bonds shown as broken lines.

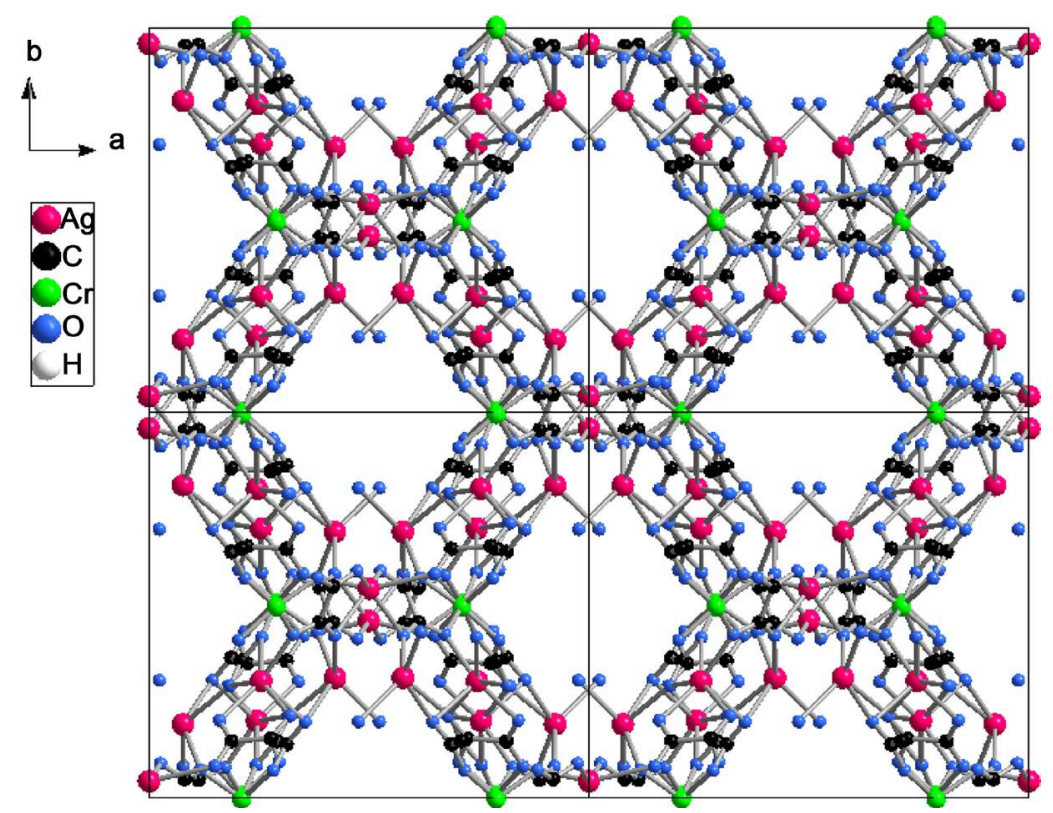

Figure 7. Large cross-section of the three-dimensional structure packing of 1 projected down [001], emphasizing the channels which are well isolated from one another by thick walls.

do-tubes are well isolated from one another by thick walls. The nanochannel structure of 1 is reminiscent of aluminosilicate zeolites [25], hybrid openframework iron phosphate-oxalates [26] [27], the family of compounds with a variable Ag-Cr-oxalate channel lattice, formulated as $\left[\left(\mathrm{M}_{\mathrm{x}} \mathrm{Ag}_{0.50-\mathrm{x}}\right)\left(\mathrm{H}_{2} \mathrm{O}\right)_{3}\right] @$ $\left[\mathrm{Ag}_{2.50} \mathrm{Cr}\left(\mathrm{C}_{2} \mathrm{O}_{4}\right)_{3}\right](0 \leq \mathrm{x} \leq 0.50 ; \mathrm{M}=\mathrm{K}, \mathrm{Cs}, \mathrm{Ag})$ [11], and most importantly, the compound, $\mathrm{Ag}_{11.60} \mathrm{H}_{0.40}\left[\mathrm{Cr}\left(\mathrm{C}_{2} \mathrm{O}_{4}\right)_{3}\right]_{4} \cdot 15 \mathrm{H}_{2} \mathrm{O}$ [12]. On comparing the structures of $\mathrm{Ag}_{11.60} \mathrm{H}_{0.40}\left[\mathrm{Cr}\left(\mathrm{C}_{2} \mathrm{O}_{4}\right)_{3}\right]_{4} \cdot 15 \mathrm{H}_{2} \mathrm{O}$ [12] and $\mathrm{Ag}_{2.50} \mathrm{H}_{0.50}\left[\mathrm{Cr}\left(\mathrm{C}_{2} \mathrm{O}_{4}\right)_{3}\right] \cdot 5 \mathrm{H}_{2} \mathrm{O}$ (1), the two main differences seem to be: a) the composition of their lattice grids: $\left[\mathrm{Ag}_{2.90} \mathrm{Cr}\left(\mathrm{C}_{2} \mathrm{O}_{4}\right)_{3}\right]^{0.10-}$ in the former compound (silver charge deficit: 0.10 offset by $\left.0.10 \mathrm{H}^{+}\right)$and $\left[\mathrm{Ag}_{2.50} \mathrm{Cr}\left(\mathrm{C}_{2} \mathrm{O}_{4}\right)_{3}\right]^{0.50-}$ in the latter (silver charge deficit: 0.50 offset by $0.50 \mathrm{H}^{+}$); b) their space groups: $P 2_{1} / \mathrm{n}$ for the former compound and $C 2 / \mathrm{c}$ for the present case. It is worth noting that the equivalent charge from $0.50 \mathrm{H}^{+}$ compensating the silver charge deficit of 0.50 in compound 1 is, to the best of 
Table 3. Structural data and host lattice networks for 11 selected nanochannel $\mathrm{Ag}(\mathrm{I}) / \mathrm{Cr}(\mathrm{III})$ oxalate coordination polymers.

\begin{tabular}{|c|c|c|c|c|}
\hline Compound $^{\mathrm{a}}$ & Host lattice network & Charge balance & Total silver deficit & Refs. \\
\hline $\mathrm{Ag}_{0.50}\left[\mathrm{Ag}_{2.50} \mathrm{Cr}(\mathrm{ox})_{3}\right]\left(\mathrm{H}_{2} \mathrm{O}\right)_{3}$ & {$\left[\mathrm{Ag}_{2.5} \mathrm{Cr}(\mathrm{ox})_{3}\right]^{0.50-}$} & {$\left[\mathrm{Ag}_{0.50}\right]^{0.50+}$} & 0.00 & \multirow{5}{*}[11]{} \\
\hline $\mathrm{K}_{0.28} \mathrm{Ag}_{0.22}\left[\mathrm{Ag}_{2.50} \mathrm{Cr}(\mathrm{ox})_{3}\right]\left(\mathrm{H}_{2} \mathrm{O}\right)_{3}$ & {$\left[\mathrm{Ag}_{2.50} \mathrm{Cr}(\mathrm{ox})_{3}\right]^{0.50-}$} & {$\left[\mathrm{K}_{0.28} \mathrm{Ag}_{0.22}\right]^{0.50+}$} & 0.28 & \\
\hline $\mathrm{Cs}_{0.19} \mathrm{Ag}_{0.31}\left[\mathrm{Ag}_{2.50} \mathrm{Cr}(\mathrm{ox})_{3}\right]\left(\mathrm{H}_{2} \mathrm{O}\right)_{3}$ & {$\left[\mathrm{Ag}_{2.50} \mathrm{Cr}(\mathrm{ox})_{3}\right]^{0.50-}$} & {$\left[\mathrm{Cs}_{0.19} \mathrm{Ag}_{0.31}\right]^{0.50+}$} & 0.19 & \\
\hline $\mathrm{Cs}_{0.41} \mathrm{Ag}_{0.09}\left[\mathrm{Ag}_{2.50} \mathrm{Cr}(\mathrm{ox})_{3}\right]\left(\mathrm{H}_{2} \mathrm{O}\right)_{3}$ & {$\left[\mathrm{Ag}_{2.50} \mathrm{Cr}(\mathrm{ox})_{3}\right]^{0.50-}$} & {$\left[\mathrm{Cs}_{0.41} \mathrm{Ag}_{0.09}\right]^{0.50+}$} & 0.41 & \\
\hline $\mathrm{Cs}_{0.43} \mathrm{Ag}_{0.07}\left[\mathrm{Ag}_{2.50} \mathrm{Cr}(\mathrm{ox})_{3}\right]\left(\mathrm{H}_{2} \mathrm{O}\right)_{3}$ & {$\left[\mathrm{Ag}_{2.50} \mathrm{Cr}(\mathrm{ox})_{3}\right]^{0.50-}$} & {$\left[\mathrm{Cs}_{0.43} \mathrm{Ag}_{0.07}\right]^{0.50+}$} & 0.43 & \\
\hline $\mathrm{H}_{0.10}\left[\mathrm{Ag}_{2.90} \mathrm{Cr}(\mathrm{ox})_{3}\right] \cdot 3.75 \mathrm{H}_{2} \mathrm{O}$ & {$\left[\mathrm{Ag}_{2.90} \mathrm{Cr}(\mathrm{ox})_{3}\right]^{0.10-}$} & {$\left[\mathrm{H}_{0.10}\right]^{0.10+}$} & 0.10 & {$[12]$} \\
\hline$\left[\left(\mathrm{Ag}_{0.25} / \mathrm{Cr}_{0.25}\right)\left(\mathrm{H}_{2} \mathrm{O}\right) @\left[\mathrm{Ag}_{2} \mathrm{Cr}(\mathrm{ox})_{3}\right] \cdot 4 \mathrm{H}_{2} \mathrm{O}\right.$ & {$\left[\mathrm{Ag}_{2} \mathrm{Cr}(\mathrm{ox})_{3}\right]^{-}$} & {$\left[\left(\mathrm{Ag}_{0.25} \mathrm{Cr}_{0.25}\right)\right]^{+}$} & 0.75 & \multirow{2}{*}[13]{} \\
\hline$\left[\left(\mathrm{Ag}_{0.25} / \mathrm{Co}_{0.25}\right)\left(\mathrm{H}_{2} \mathrm{O}\right) @\left[\mathrm{Ag}_{2} \mathrm{Co}(\mathrm{ox})_{3}\right] \cdot 4 \mathrm{H}_{2} \mathrm{O}\right.$ & {$\left[\mathrm{Ag}_{2} \mathrm{Co}(\mathrm{ox})_{3}\right]^{-}$} & {$\left[\left(\mathrm{Ag}_{0.25} \mathrm{Co}_{0.25}\right)\right]^{+}$} & 0.75 & \\
\hline $\mathrm{K}_{0.70}\left[\mathrm{Ag}_{2.30} \mathrm{Co}(\mathrm{ox})_{3}\right] \cdot 3 \mathrm{H}_{2} \mathrm{O}$ & {$\left[\mathrm{Ag}_{2.30} \mathrm{Co}(\mathrm{ox})_{3}\right]^{0.70-}$} & {$\left[\mathrm{K}_{0.70}\right]^{0.70+}$} & 0.70 & {$[23]$} \\
\hline $\mathrm{Ag}_{0.26} \mathrm{~K}_{0.24}\left[\mathrm{Ag}_{2.50} \mathrm{Cr}(\mathrm{ox})_{3}\right] \cdot 3 \mathrm{H}_{2} \mathrm{O}$ & {$\left[\mathrm{Ag}_{2.50} \mathrm{Cr}(\mathrm{ox})_{3}\right]^{0.50-}$} & {$\left[\mathrm{K}_{0.24} \mathrm{Ag}_{0.26}\right]^{0.50+}$} & 0.24 & {$[24]$} \\
\hline $\mathrm{Ag}_{2.50} \mathrm{H}_{0.50}\left[\mathrm{Cr}(\mathrm{ox})_{3}\right] \cdot 5 \mathrm{H}_{2} \mathrm{O}$ & {$\left[\mathrm{Ag}_{2.50} \mathrm{Cr}(\mathrm{ox})_{3}\right]^{0.50-}$} & $0.50 \mathrm{H}^{+}$ & 0.50 & This work \\
\hline
\end{tabular}

${ }^{\mathrm{a}} \mathrm{Ox}=$ dianion oxalate $\left(\mathrm{C}_{2} \mathrm{O}_{4}^{2-}\right)$.

our knowledge, the highest value observed so far for this family of materials. Structural data and compositions of a series of host lattice networks for some selected nanochannel $\mathrm{Ag}(\mathrm{I}) / \mathrm{Cr}$ (III)-oxalate complexes are summarized in Table 3, illustrating that these compounds predominantly crystallize in the monoclinic system, space group $C 2 / \mathrm{c}$. A channel lattice network with the chemical composition $\left[\mathrm{Ag}_{2} \mathrm{Cr}\left(\mathrm{C}_{2} \mathrm{O}_{4}\right)_{3}\right]^{-}$was found in the structure of the compound $\mathrm{Ba}_{0.5} \mathrm{Ag}_{2}$ $\left[\mathrm{Cr}\left(\mathrm{C}_{2} \mathrm{O}_{4}\right)_{3}\right] \cdot 5 \mathrm{H}_{2} \mathrm{O}$ (silver deficit: 1) [15], yet, with excess negative charge (1-) compensated not by protons, but rather by an equivalent cationic charge from $0.5 \mathrm{Ba}^{2+}$. In light of this latter result, it now appears likely that the proton content in Ag-Cr-oxalate channel lattices can be adjusted to the stoichiometric formula $\mathrm{Ag}_{2} \mathrm{H}\left[\mathrm{Cr}\left(\mathrm{C}_{2} \mathrm{O}_{4}\right)_{3}\right] \cdot \mathrm{nH}_{2} \mathrm{O}$ [13]. Such materials with protons residing within "hydrogen-bonded water molecules" in the channels are expected to exhibit very high proton conductivity [28]-[33].

\section{Conclusion}

A new open framework silver-deficient complex salt, $\operatorname{Ag}_{2.50} \mathrm{H}_{0.50}\left[\mathrm{Cr}\left(\mathrm{C}_{2} \mathrm{O}_{4}\right)_{3}\right] \cdot 5 \mathrm{H}_{2} \mathrm{O}$ $(1)$, has been obtained from an acidic aqueous medium $(\mathrm{pH} \approx 3)$ as violet elongated crystals. Compound 1 self-assembles into a 3D network with nanochannels accommodating hydrogen-bonded water molecules and protons. A feature of paramount interest in the present structure is the compensation of the negative charge $(0.50-)$ of the lattice grid $\left[\mathrm{Ag}_{2.50} \mathrm{Cr}\left(\mathrm{C}_{2} \mathrm{O}_{4}\right)_{3}\right]^{0.50-}$ by exclusively an equivalent charge from $0.50 \mathrm{H}^{+}$embedded in the channels, the highest amount of protons, indeed, known so far for this family of compounds. In continuation of the present work, the results of which demonstrate the great synthetic flexibility for the construction of supramolecular assemblies, our forthcoming researches will definitely be focused on the preparation of other members of this family of silver-deficient coordination polymers. Our main concern, thereby, 
shall be targeted at the attempts to obtain both the ultimate deficiency of $1 \mathrm{Ag}^{+}$ ion per formula unit and an equivalent charge balance of $1 \mathrm{H}^{+}$, thus leading to the ideal stoichiometric chemical composition $\mathrm{Ag}_{2} \mathrm{H}\left[\mathrm{Cr}\left(\mathrm{C}_{2} \mathrm{O}_{4}\right)_{3}\right] \cdot \mathrm{nH}_{2} \mathrm{O}$ [13]. Evidence of the protonic charge allowed migrating very fast up and down within the "water clusters" in the channels bears testimony to the renewed interest in this class of open framework materials. Moreover, materials of this type with large cavities may possess gas absorptive ability. Work in this direction is in progress in our lab.

\section{Supplementary Material}

Crystallographic data of compound 1 have been deposited at the Cambridge Crystallographic Data Centre, CCDC 875775. These data can be obtained free of charge from the Cambridge Crystallographic Data Centre via

http://www.ccdc.cam.ac.uk/data_request/cif.

\section{Acknowledgements}

We thank Prof. You Song (Nanjing University, China) for his help with the $\mathrm{X}$-ray structural analysis and valuable suggestions.

\section{References}

[1] Flanigen, E.M., Jansen, J.C. and Bekkum, H.V. (1991) Introduction to Zeolite Science and Practice. Elsevier, New York.

[2] Cheetham, A.K., Férey, G. and Loiseau, T. (1999) Open Framework Inorganic Materials. Angewandte Chemie International Edition, 38, 3268-3292. https://doi.org/10.1002/(SICI)1521-3773(19991115)38:22<3268::AID-ANIE3268>3. $\underline{0 . \mathrm{CO} ; 2-\mathrm{U}}$

[3] Lee, J.Y., Farha, O.K., Roberts, J., Scheidt, K.A., Nguyen, S.T. and Hupp, J.T. (2009) Metal-Organic Framework Materials as Catalysts. Chemistry Society Reviews, 38, 1450-459. https://doi.org/10.1039/b807080f

[4] Zhang, X.M., Wang, Y.Q., Wang, K., Gao, E.Q. and Liu, C.M. (2011) Metamagnetism and Slow Magnetic Dynamics in an Antiferromagnet Composed of Cobalt(II) Chains with Mixed Azide-Carboxylate Bridges. Chemistry Communications, 47, 1815-1817. https://doi.org/10.1039/C0CC04492J

[5] Coe, B.J., Foxon, S.P., Harper, E.C., Helliwell, M., Raftery, J., Swanson, C.A., Brunschwig, B.S., Clays, K., Franz, E., Garin, J., Orduna, J., Horton, P.N. and Hursthouse, M.B. (2010) Evolution of Linear Absorption and Nonlinear Optical Properties in V-Shaped Ruthenium(II)-Based Chromophores. Journal of the American Chemical Society, 132, 1706-1723. https://doi.org/10.1021/ja908667p

[6] Yaghi, O.M., O’Keeffe, M., Ockwig, N.W., Chae, H.K., Eddaoudi, M. and Kim, J. (2003) Reticular Synthesis and the Design of New Materials. Nature, 423, 705-714. https://doi.org/10.1038/nature01650

[7] Kesanli, B., Cui, Y., Smith, M.R., Bittner, E.W., Bockrath, B.C. and Lin, W. (2005) Highly Interpenetrated Metal-Organic Frameworks for Hydrogen Storage. Angewandte Chemie International Edition, 44, 72-75. https://doi.org/10.1002/anie.200461214

[8] Lim, C.S., Schnobrich, J.K., Wong-Foy, A.G. and Matzger, A.J. (2010) Met- 
al-Dependent Phase Selection in Coordination Polymers Derived from a $C_{2 v}$-Symmetric Tricarboxylate. Inorganic Chemistry, 49, 5271-5275.

https://doi.org/10.1021/ic100378p

[9] Kitagawa, S., Kitaura, R. and Noro, S.I. (2004) Functional Porous Coordination Polymers. Angewandte Chemie International Edition, 43, 2334-2375.

https://doi.org/10.1002/anie.200300610

[10] Choudhury, A., Natarajan, S. and Rao, C.N.R. (2000) Hybrid Open-Framework Iron Phosphate-Oxalates Demonstrating a Dual Role of the Oxalate Unit. Chemistry-A European Journal, 6, 1168-1175.

https://doi.org/10.1002/(SICI)1521-3765(20000403)6:7<1168::AID-CHEM1168>3.3. CO;2-J

[11] Dean, P.A.W., Craig, D., Dance, I., Russell, V. and Scudder, M. (2004) A Variable Ag-Cr-Oxalate Channel Lattice: $\left[\mathrm{M}_{\mathrm{x}} \mathrm{Ag}_{0.5-\mathrm{x}}\left(\mathrm{H}_{2} \mathrm{O}\right)_{3}\right] @\left[\mathrm{Ag}_{2.5} \mathrm{Cr}\left(\mathrm{C}_{2} \mathrm{O}_{4}\right)_{3}\right], \mathrm{M}=\mathrm{K}, \mathrm{Cs}$, Ag. Inorganic Chemistry, 43, 443-449. https://doi.org/10.1021/ic034988k

[12] Bélombé, M.M., Nenwa, J., Mbiangué, Y.A., Gouet, B., Majoumo, F., Hey-Hawkins, E. and Lönnecke, P. (2009) Water-Filled Pseudo-Nanotubes in $\mathrm{Ag}_{11.60} \mathrm{H}_{0.40^{-}}$ $\left[\mathrm{Cr}\left(\mathrm{C}_{2} \mathrm{O}_{4}\right)_{3}\right]_{4} \cdot 15 \mathrm{H}_{2} \mathrm{O}$ : Synthesis, Characterization and $\mathrm{X}$-Ray Structure. Inorganica Chimica Acta, 362, 1-4.

[13] Bélombé, M.M., Nenwa, J., Tene, O.T. and Fokwa, B.P.T. (2010) Synthesis, X-Ray Structure and Thermal Behavior of Isomorphous Silver-Deficient Channel Lattice Frameworks with General Formula $\left[\left(\mathrm{Ag}_{0.25} / \mathrm{M}_{0.25}\right)\left(\mathrm{H}_{2} \mathrm{O}\right)\right] @\left[\mathrm{Ag}_{2} \mathrm{M}\left(\mathrm{C}_{2} \mathrm{O}_{4}\right)_{3}\right] \cdot 4 \mathrm{H}_{2} \mathrm{O}(\mathrm{M}$ $\left.=\mathrm{Co}^{\mathrm{III}}, \mathrm{Cr}^{\mathrm{III}}\right)$. Global Journal of Inorganic Chemistry, 1, 34-41.

[14] Mbiangué, Y.A., Nenwa, J., Bélombé, M.M., Ngoune, J. and Álvarez, E. (2012) Hydrogen-Bonded Pillars of Alternating Chiral Complex Cations and Anions: 2. Synthesis, Characterization and X-Ray Structure of Isomorphous catena- $\left\{\left(\mathrm{H}_{3} \mathrm{O}\right)\right.$ $\left.\left[\mathrm{K}\left(\mathrm{H}_{2} \mathrm{O}\right)_{3}\right] @\left[\mathrm{Ni}\left(\mathrm{H}_{2} \text { oxado }\right)_{3}\right]_{2}\left[\mathrm{Cr}\left(\mathrm{C}_{2} \mathrm{O}_{4}\right)_{3}\right]_{2} \cdot 3 \mathrm{H}_{2} \mathrm{O}\right\}$ and catena- $\left\{\left(\mathrm{H}_{3} \mathrm{O}\right)\left[\mathrm{Li}\left(\mathrm{H}_{2} \mathrm{O}\right)_{3}\right] @[\mathrm{Ni}-\right.$ $\left.\left(\mathrm{H}_{2} \text { oxado }\right)_{3}\right]_{2}\left[\mathrm{Cr}\left(\mathrm{C}_{2} \mathrm{O}_{4}\right)_{3}\right]_{2} \cdot 3 \mathrm{H}_{2} \mathrm{O}$. ScienceJet, $1,1-9$.

[15] Eboga-Tanke, C., Ndosiri, B.N., Mbiangué, Y.A., Bebga, G. and Nenwa, J. (2016) Synthesis, Characterization and X-Ray Structure of a $\mathrm{Ba}(\mathrm{II}) / \mathrm{Ag}(\mathrm{I}) / \mathrm{Cr}$ (III)-Oxalate Salt with Water-Filled Nanochannels. American Journal of Analytical Chemistry, 7, 99-106. https://doi.org/10.4236/ajac.2016.71010

[16] Sheldrick, G.M. (1999) SADABS. University of Göttingen, Göttingen, Germany.

[17] Sheldrick, G.M. (1997) SHELXS-97. University of Göttingen, Göttingen, Germany.

[18] Sheldrick, G.M. (1997) SHELXL-97. University of Göttingen, Göttingen, Germany.

[19] Farrugia, L.J. (1997) ORTEP-3 for Windows-A Version of ORTEP-III with a Graphical User Interface (GUI). Journal of Applied Crystallography, 30, 565. https://doi.org/10.1107/S0021889897003117

[20] Farrugia, L.J. (1999) WinGX Suite for Small-Molecule Single-Crystal Crystallography. Journal of Applied Crystallography, 32, 837-838. https://doi.org/10.1107/S0021889899006020

[21] Xu, N., Xing, Y., Liu, X., Song, D., Ma, L. and Sun, X. (2009) Synthesis, Structure and Photoluminescent Properties of $\left[\mathrm{C}_{6} \mathrm{~N}_{2} \mathrm{H}_{14}\right]\left[\mathrm{Nd}_{2}\left(\mathrm{C}_{2} \mathrm{O}_{4}\right)_{2}\left(\mathrm{SO}_{4}\right)_{2}\left(\mathrm{H}_{2} \mathrm{O}\right)_{4}\right] \cdot \mathrm{H}_{2} \mathrm{O}$, a New Organically Templated Neodymium(III) Oxalate-Sulfate. Zeitschrift für Anorganische und Allgemeine Chemie, 635, 558-562. https://doi.org/10.1002/zaac.200801309

[22] Prokhorova, T.G., Khasanov, S.S., Zorina, L.V., Buravov, L.I., Tkacheva, V.A., Baskakov, A.A., Morgunov, R.B., Gener, M., Canadell, E., Shibaeva, R.P. and Yagubskii, E.B. (2003) Molecular Metals Based on BEDT-TTF Radical Cation Salts with Magnetic Metal Oxalates as Counterions: $\beta$ "'-(BEDT-TTF $)_{4} \mathrm{~A}\left[\mathrm{M}\left(\mathrm{C}_{2} \mathrm{O}_{4}\right)_{3}\right] \cdot \mathrm{DMF}$ $\left(\mathrm{A}=\mathrm{NH}_{4}^{+}, \mathrm{K}^{+} ; \mathrm{M}=\mathrm{Cr}^{\mathrm{III}}, \mathrm{Fe}^{\mathrm{III}}\right)$. Advanced Functional Materials, 13, 403-411. 
https://doi.org/10.1002/adfm.200304283

[23] Nenwa, J., Gouet, B., Djonwouo, P.L. and Fokwa, B.P.T. (2012) Synthesis, X-Ray Structure and Spectroscopic Characterization of a Non-Stoichiometric Nanostructured Silver Salt Hosting Water-Guest Molecules. Research Journal of Chemistry and Environment, 16, 111-115.

[24] Gouet, B., Signé, M., Nenwa, J. and Fokwa, B.P.T. (2013) Synthesis, Crystal Structure and Spectroscopic Characterization of an Oxalato Bridged Silver-Deficient Chromium(III) Salt with Water-Filled Nanochannels. Research Journal of Chemistry and Environment, 17, 57-63.

[25] Meier, W.M., Olson, D.H. and Baerlocher, C. (1996) Atlas of Zeolite Structure Types. 4th Edition, Elsevier, New York, 308 p.

[26] Rao, C.N.R. and Nath, H. (2003) Inorganic Nanotubes. Dalton Transactions, No. 1, 1-24. https://doi.org/10.1039/b208990b

[27] Choudhury, A., Natarajan, S. and Rao, C.N.R. (1999) A Hybrid Open-Framework Iron Phosphate-Oxalate with a Large Unidimensional Channel, Showing Reversible Hydration. Chemistry of Materials, 11, 2316-2318. https://doi.org/10.1021/cm9903430

[28] Wicke, E., Eigen, M. and Ackermann, Th. (1954) Über den Zustand des Protons (Hydroniumions) in wäßriger Lösung. Zeitschrift für Physikalische Chemie, 1, 5-6. https://doi.org/10.1524/zpch.1954.1.5_6.340

[29] Kreuer, K.D. (1996) Proton Conductivity: Materials and Applications. Chemistry of Materials, 8, 610-641. https://doi.org/10.1021/cm950192a

[30] Rashid, S., Turner, S.S., Day, P., Light, M.E., Hursthouse, M.B., Firth, S. and Clark, R.J.H. (2001) The First Molecular Charge Transfer Salt Containing Proton Channels. Chemical Communications, No. 16, 1462-1463. https://doi.org/10.1039/b103877j

[31] Martin, L., Day, P., Clegg, W., Harrington, R.W., Horton, P.N., Bingham, A., Hursthouse, M.B., McMilan, P. and Firth, S. (2007) Multi-Layered Molecular Charge Transfer Salts Containing Alkali Metal Ions. Journal of Materials Chemistry, 17, 3324-3329. https://doi.org/10.1039/b702442h

[32] Nenwa, J., Eboga-Tanke, C., Bebga, G., Djonwouo, P.L. and Ngouné, J. (2016) Nanostructured Silver-Deficient Coordination Polymers Hosting Water-Guest Molecules. 1st Pan-African Conference on Crystallography ( $\left.\mathrm{PCCr}^{1}\right)$, Dschang, Cameroon, 6-10 October, Oral Abstract, 128.

[33] Akutsu-Sato, A., Akutsu, H., Turner, S.S., Day, P., Probert, M.R., Howard, J.A.K., Akutagawa, T., Takeda, S., Nakamura, T. and Mori, T. (2005) The First ProtonConducting Metallic Ion-Radical Salts. Angewandte Chemie International Edition, 44, 292-295. https://doi.org/10.1002/anie.200461686 
Submit or recommend next manuscript to SCIRP and we will provide best service for you:

Accepting pre-submission inquiries through Email, Facebook, LinkedIn, Twitter, etc. A wide selection of journals (inclusive of 9 subjects, more than 200 journals)

Providing 24-hour high-quality service

User-friendly online submission system

Fair and swift peer-review system

Efficient typesetting and proofreading procedure

Display of the result of downloads and visits, as well as the number of cited articles Maximum dissemination of your research work

Submit your manuscript at: http://papersubmission.scirp.org/

Or contact ojic@scirp.org 